\title{
Uptake of Individual Isomers of 2,6-Diaminopimelate and their Incorporation into Walls during Growth of Bacillus megaterium
}

\author{
By A. DAY* AND P. J. WHITE \\ Department of Microbiology, The University, Sheffield S10 2TN
}

(Received 22 June 1978; revised 22 August 1978)

\begin{abstract}
Bacillus megaterium NCIB 7581, when growing exponentially in a simple chemically defined medium (without 2,6-diaminopimelic acid), contained only $4 \mathrm{~mm}$-diaminopimelate in the free amino acid pool; this diaminopimelate was $84 \%(\mathrm{w} / \mathrm{w})$ meso-isomer and $16 \%$ LL-isomer. Growing organisms could take up any of the three isomers of diaminopimelate from the medium, though the DD-isomer was taken up at only half the rate of the other two isomers (meso- and LL-). When lysine was also present in the medium, most $(70 \%, \mathrm{w} / \mathrm{w})$ of the diaminopimelate that was taken up entered peptidoglycan; only about $5 \%$ of the total uptake was into the free amino acid pool. When DD-diamino $\left[{ }^{14} \mathrm{C}\right]$ pimelate was supplied in the medium, $86 \%$ of the diamino $\left[{ }^{14} \mathrm{C}\right]$ pimelate incorporated into peptidoglycan was present as the meso-isomer and $14 \%$ was the DD-isomer.
\end{abstract}

\section{INTRODUCTION}

The wall of Bacillus megaterium NCIB 7581 contains all three isomers of 2,6-diaminopimelic acid $\left(\mathrm{A}_{2} \mathrm{pm}\right)$ in the following proportions $(\%, \mathrm{w} / \mathrm{w}):$ meso-, $75 ; \mathrm{LL}-, 18 ; \mathrm{DD}-, 7$ (Day \& White, 1977). If free DD- $\mathrm{A}_{2}$ pm were to be found in the amino acid pool, this would support the view that $\mathrm{DD}-\mathrm{A}_{2} \mathrm{pm}$ was really present in the wall and had not arisen solely by isomerization during acid hydrolysis of the peptidoglycan. The concentrations of the individual isomers of $\mathrm{A}_{2} \mathrm{pm}$ in the amino acid pool of this organism have therefore been studied. The uptake of each separate isomer of $\mathrm{A}_{2} \mathrm{pm}$ and its subsequent metabolism have also been examined with growing cultures, and the conversion of DD- $\mathrm{A}_{2} \mathrm{pm}$ into meso- $\mathrm{A}_{2} \mathrm{pm}$ has been recognized for the first time.

\section{METHODS}

Organism. Bacillus megaterium NCIB 7581 was used throughout and was maintained as described by Day \& White (1977).

Medium. Medium A2 (White, 1972) containing biotin $\left(20 \mu \mathrm{g} \mathrm{l}^{-1}\right)$ was used.

Conditions of growth. Organisms were grown at $37^{\circ} \mathrm{C}$ in $500 \mathrm{ml}$ medium in shaken flasks (2 l) and growth was assessed turbidimetrically as described previously (White, 1972).

Preparation of enzymes. Diaminopimelate decarboxylase (EC 4.1.1.20; meso-2,6-diaminopimelate carboxy-lyase) and diaminopimelate epimerase (EC 5.1.1.7; 2,6-LL-diaminopimelate 2-epimerase) were partially purified (for use in assays for isomers of $\mathrm{A}_{2} \mathrm{pm}$ ) as described by Day \& White (1977).

Assays for isomers of $A_{2} \mathrm{pm}$. Colorimetric and manometric methods (Day \& White, 1977) were used. In addition, isomers of $\left[{ }^{14} \mathrm{C}\right] \mathrm{A}_{2} \mathrm{pm}$ and $\left[{ }^{14} \mathrm{C}\right]$ lysine were separated by paper chromatography (see below) and then the radioactivity in each was measured.

Preparation of isomers of $A_{2} \mathrm{pm}$. The unlabelled isomers were isolated as described by Day \& White (1977).

Isolation of isomers of $\left[{ }^{14} \mathrm{C}\right] \mathrm{A}_{2} \mathrm{pm}$. (i) meso- $\left[{ }^{14} \mathrm{C}\right] \mathrm{A}_{2} \mathrm{pm}$. $\left[1,(7)-{ }^{14} \mathrm{C}\right] \mathrm{A}_{2} \mathrm{pm}(5 \mu \mathrm{Ci}$; about $100 \mu \mathrm{g})$ was dis-

* Present address: Process Research Department, Allied Breweries (Production) Ltd, Burton-on-Trent, Staffordshire DE14 1BZ. 
solved in water $(2 \mathrm{ml})$ containing meso- $\mathrm{A}_{2} \mathrm{pm}(5 \mathrm{mg})$ and ethanol was added until a faint turbidity persisted. The solution was left overnight at room temperature and the precipitate was then collected by centrifuging. Ethanol was again added to the supernatant liquid until it was just turbid and next day the precipitate was collected by centrifuging. Each precipitate was washed in $1 \mathrm{ml}$ water at $2{ }^{\circ} \mathrm{C}$ and the solid $\left(m e s o\left[{ }^{14} \mathrm{C}\right] \mathrm{A}_{2} \mathrm{pm}\right)$ was collected by filtration and dried over $\mathrm{P}_{2} \mathrm{O}_{5}$. The filtrate was added to the supernatant liquids from the two earlier centrifugations and the solution was dried by evaporation at $35^{\circ} \mathrm{C}$ to give crude $\mathrm{LL}_{-}\left[{ }^{14} \mathrm{C}\right] \mathrm{A}_{2} \mathrm{pm}$ plus DD- $\left[{ }^{14} \mathrm{C}\right] \mathrm{A}_{2} \mathrm{pm}$.

(ii) LL- $\left[{ }^{[4} \mathrm{C}\right] \mathrm{A}_{2} \mathrm{pm}$ and $\mathrm{DD}-\left[{ }^{14} \mathrm{C}\right] \mathrm{A}_{2} \mathrm{pm}$. The crude preparation (see above) was redissolved in $0 \cdot 1$ M-phosphate buffer, $\mathrm{pH} 6.8(1.75 \mathrm{ml})$, and pyridoxal phosphate $(10 \mu \mathrm{g}), 2,3$-dimercaptopropan-1-ol (to give $1 \mathrm{~mm}$ ) and diaminopimelate decarboxylase ( 0.14 unit) were added in a final volume of $2.5 \mathrm{ml}$. A similar flask, containing meso- $\mathrm{A}_{2} \mathrm{pm}(1 \mathrm{mg})$ in place of the radioactive material, was set up as a control for the completeness of the enzymic conversion of the meso-isomer to lysine. The flasks were shaken at $37^{\circ} \mathrm{C}$ for $1.5 \mathrm{~h}$, by which time no $\mathrm{A}_{2} \mathrm{pm}$ remained in the control flask.

Ethanol $(7.5 \mathrm{ml})$ was added to deproteinize the radioactive solution. After $1 \mathrm{~h}$ the precipitate was removed by centrifuging and unlabelled DD- and LL- $\mathrm{A}_{2} \mathrm{pm}$ (each $100 \mu \mathrm{g}$ ) were added as carriers of the radioactive material. The mixture was then desalted on a column $(6 \times 0.5 \mathrm{~cm})$ of Dowex $50\left(\mathrm{H}^{+}-\right.$form, $8 \%$ crosslinking). The $\mathrm{A}_{2} \mathrm{pm}$ was eluted with $1 \mathrm{M}-\mathrm{NH}_{4} \mathrm{OH}$; the eluate was dried, taken up in water $(0 \cdot 2 \mathrm{ml})$ and applied as a streak to the origin of a paper chromatogram which was developed with solvent 2 (see below) overnight and then dried at room temperature in a stream of air for $24 \mathrm{~h}$. A guide strip with markers of LLand DD- $\mathrm{A}_{2} \mathrm{pm}$ was cut off and treated with ninhydrin. Areas on the chromatogram that corresponded to the positions of the markers were cut out and eluted with water by descending chromatography. The separate eluates of $\mathrm{LL}_{-}\left[{ }^{14} \mathrm{C}\right] \mathrm{A}_{2} \mathrm{pm}$ and $\mathrm{DD}-\left[{ }^{[4} \mathrm{C}\right] \mathrm{A}_{2} \mathrm{pm}$ were dried.

Each radioactive isomer was dissolved in water, assayed colorimetrically for $\mathrm{A}_{2} \mathrm{pm}$ and counted. A sample of each solution was incubated with diaminopimelate decarboxylase and then chromatographed (solvent 1). Proportions of LL- and DD-isomers were determined from the radioactivity in the appropriate areas of the chromatogram; meso- $\mathrm{A}_{2} \mathrm{pm}$ was assessed from the radioactivity in the lysine area, which was doubled to correct for loss of ${ }^{14} \mathrm{CO}_{2}$ from the meso- $\left[{ }^{14} \mathrm{C}\right] \mathrm{A}_{2} \mathrm{pm}$. The yield of meso- $\left[{ }^{14} \mathrm{C}\right] \mathrm{A}_{2} \mathrm{pm}$ was $71 \%$ (of the meso$\left[{ }^{14} \mathrm{C}\right] \mathrm{A}_{2} \mathrm{pm}$ present in the starting material); its specific activity was $0.087 \mu \mathrm{Ci} \mu \mathrm{mol}^{-1}$ and $88 \%$ of this radioactivity was present as meso- $\mathrm{A}_{2} \mathrm{pm}, 6 \%$ was $\mathrm{LL}-\mathrm{A}_{2} \mathrm{pm}$ and $6 \%$ was DD- $\mathrm{A}_{2} \mathrm{pm}$, although the contamination expressed as a percentage by weight would be negligible. The yield of $L L-\left[{ }^{14} \mathrm{C}\right] \mathrm{A}_{2} \mathrm{pm}$ was $68 \%$; its specific activity was $3 \cdot 2 \mu \mathrm{Ci} \mu \mathrm{mol}^{-1}$ and $96 \%$ of this radioactivity was present as $L L-A_{2}$ pm and $4 \%$ was DD-A $A_{2} \mathrm{pm}$. The yield of $\mathrm{DD}-\left[{ }^{14} \mathrm{C}\right] \mathrm{A}_{2} \mathrm{pm}$ was $66 \%$; its specific activity was $3.4 \mu \mathrm{Ci} \mu \mathrm{mol}^{-1}$ and $95 \%$ of this radioactivity was present as $\mathrm{DD}-\mathrm{A}_{2} \mathrm{pm}$ and $5 \%$ was $\mathrm{LL}-\mathrm{A}_{2} \mathrm{pm}$. No radioactive meso- $\mathrm{A}_{2} \mathrm{pm}$ was detected in the labelled LL- or DD-isomers, probably because of the use of diaminopimelate decarboxylase in their isolation.

Paper chromatography and electrophoresis. Descending chromatograms on Whatman no. 1 paper were developed with solvent 1 (Rhuland et al., 1955): methanol/water/11.6 M-HCl/pyridine (32:7:1:4, by vol.), or solvent 2 (Perkins, 1965): methanol/water/98\% (w/v) formic acid/pyridine (80:19:1:10, by vol.). Amino acids were detected by reaction with ninhydrin. In solvent $1, \mathrm{LL}-\mathrm{A}_{2} \mathrm{pm}$ had a higher mobility than either the meso- or DD-isomers, which ran almost together, and lysine ran well in front of $L L-\mathrm{A}_{2} \mathrm{pm}$. Solvent 2 was used when $\mathrm{A}_{2} \mathrm{pm}$ was subsequently to be eluted (for purposes other than measuring radioactivity), so as to avoid eluting pyridine hydrochloride, which interfered in further manipulations.

Electrophoresis was carried out on Whatman no. 1 or $3 \mathrm{MM}$ paper at $45 \mathrm{~V} \mathrm{~cm}^{-1}$ and about $50 \mathrm{~mA}$ for $1 \mathrm{~h}$ in a Savant FP22A apparatus with a Savant HV5000A power supply (Savant Instruments, 221 Park Avenue, Hicksville, N.Y., U.S.A.). The buffer (pH 6.5) was pyridine/acetic acid/water (100:4:896, by vol.).

Extraction of the free amino acid pool. The procedure of Tempest et al. (1970) was followed. The dry weight of organisms in a culture was determined turbidimetrically; then the organisms were collected by centrifuging at $2^{\circ} \mathrm{C}$ and resuspended in ice-cold $0.25 \mathrm{M}-\mathrm{HClO}_{4}$ (about $1 \mathrm{ml}$ per $\mathrm{mg}$ dry wt bacteria). After $10 \mathrm{~min}$ at $2^{\circ} \mathrm{C}$ the suspension was centrifuged and the supernatant liquid was collected. The organisms were again treated with $0.25 \mathrm{M}-\mathrm{HClO}_{4}$ (one-quarter of the volume used for the first extraction) and the two extracts were combined and neutralized with $5 \mathrm{M}-\mathrm{KOH}$. After $1 \mathrm{~h}$ at $0^{\circ} \mathrm{C}$ the precipitated $\mathrm{KClO}_{4}$ was removed and the supernatant liquid ('pool extract') was stored at $-15^{\circ} \mathrm{C}$ until assayed for amino acids in an analyser. The volume of the pool (in $\mu$ ) was assumed to be numerically equal to four times the dry weight (in $\mathrm{mg}$ ) of the bacteria extracted (Tempest et al., 1970).

Radiochemical techniques. Labelled compounds were located by placing developed chromatograms in contact with Kodirex X-ray film for periods of up to 4 weeks. Radioactive areas detected in this way were counted with an end-window Geiger-Müller tube coupled to a scaler.

Radioactive samples were counted in a scintillation fluid (containing $7 \mathrm{~g} \mathrm{2,5-diphenyloxazole,} 0 \cdot 3 \mathrm{~g}$ 1,4-di-2-(5-phenyloxazolyl)benzene, $100 \mathrm{~g}$ naphthalene and dioxan to 11 ) in a Nuclear Chicago apparatus (model 6801). Quench corrections were made by the channels ratio method. 
Uptake of $A_{2}$ pm by growing cultures. Organisms in the exponential phase of growth in medium A2 were harvested, washed and inoculated into fresh medium containing $\mathrm{A}_{2} \mathrm{pm}$ (see Results). This suspension was shaken at $37^{\circ} \mathrm{C}$ and samples were taken at intervals for measurement of turbidity and of $\mathrm{A}_{2} \mathrm{pm}$ remaining in the medium (by colorimetric assay).

When $\left[{ }^{14} \mathrm{C}\right] \mathrm{A}_{2} \mathrm{pm}$ was used, a sample of medium $(0.5 \mathrm{ml})$ was removed immediately before inoculation for measurements of the radioactivity added and of the concentration of $\mathrm{A}_{2} \mathrm{pm}$ (by colorimetric assay). Further samples $(2 \mathrm{ml})$ were removed at intervals; the turbidity of each was measured and then the organisms were collected on a Millipore membrane $(0.45 \mu \mathrm{m}$ pore size). The membrane was washed with $0.1 \mathrm{M}-$ phosphate buffer, $\mathrm{pH} 6.8(10 \mathrm{ml})$ containing unlabelled $\mathrm{A}_{2} \mathrm{pm}\left(50 \mu \mathrm{g} \mathrm{ml}^{-1}\right.$; the same isomer as was added to the growth medium) to remove surplus radioactive medium. Radioactivity in the membrane plus organisms was then counted in scintillation fluid $(10 \mathrm{ml}$, in which the membrane dissolved). The uptake of $\mathrm{A}_{2} \mathrm{pm}$ was calculated from this radioactivity and the measured specific activity of the $\mathrm{A}_{2} \mathrm{pm}$. At the end of the incubation, the remaining culture was divided into two equal parts, and peptidoglycan was isolated from the organisms by the method of Park \& Hancock (1960). The peptidoglycan was suspended in $6 \mathrm{M}$ $\mathrm{HCl}$ and heated at $105^{\circ} \mathrm{C}$ for $18 \mathrm{~h}$ to liberate $\mathrm{A}_{2} \mathrm{pm}$. The $\mathrm{A}_{2} \mathrm{pm}$ in the hydrolysate was eluted from Dowex 50 as described by Day \& White (1977) before individual isomers were assayed.

In one experiment, organisms that had been grown with unresolved synthetic $\left[{ }^{11} \mathrm{C}\right] \mathrm{A}_{2} \mathrm{pm}$ were centrifuged, then washed with $0 \cdot 1 \mathrm{M}$-phosphate buffer, $\mathrm{pH} 6 \cdot 8(10 \mathrm{ml})$ containing unlabelled synthetic $\mathrm{A}_{2} \mathrm{pm}$ $\left(50 \mu \mathrm{g} \mathrm{ml}^{-1}\right)$. The washed organisms were hydrolysed with $6 \mathrm{M}-\mathrm{HCl}$ as described above. Peptidoglycan was also isolated from these organisms and similarly hydrolysed.

Entry of $\left[{ }^{14} \mathrm{C}\right] A_{2}$ pm into the amino acid pool. Organisms were grown in medium $\mathrm{A} 2(20 \mathrm{ml})$ containing L-lysine $\left(50 \mu \mathrm{g} \mathrm{ml}^{-1}\right)$ and either LL- or DD-A $\mathrm{A}_{2} \mathrm{pm}\left(50 \mu \mathrm{g} \mathrm{ml}^{-1}\right)$; early in the exponential phase of growth LL- $\left[{ }^{14} \mathrm{C}\right] \mathrm{A}_{2} \mathrm{pm}(0.34 \mu \mathrm{Ci})$ or $\mathrm{DD}-\left[{ }^{14} \mathrm{C}\right] \mathrm{A}_{2} \mathrm{pm}(0.33 \mu \mathrm{Ci})$ was added. At intervals, the turbidities of the cultures were measured and samples $(0.5 \mathrm{ml})$ were transferred to $0.1 \mathrm{M}$-phosphate buffer, $\mathrm{pH} 6.8(5 \mathrm{ml})$ or to $5 \%$ $(\mathrm{w} / \mathrm{v})$ trichloroacetic acid $(5 \mathrm{ml})$ at $2{ }^{\circ} \mathrm{C}$; after $10 \mathrm{~min}$ these suspensions were filtered through membrane discs, which were washed with cold buffer $(15 \mathrm{ml})$ or $5 \%$ trichloroacetic acid $(15 \mathrm{ml})$ and then counted for radioactivity. The radioactivity present in the organisms after washing with buffer was taken to represent $A_{2} p m$ in the free amino acid pool plus covalently linked $A_{2} p m$, while the radioactivity after extraction with trichloroacetic acid represented only covalently linked $A_{2}$ pm in the organisms.

Chemicals. Diamino[1,(7)- $\left.{ }^{14} \mathrm{C}\right]$ pimelic acid $\left(10 \mathrm{mCi} \mathrm{mmol}^{-1}\right)$ was purchased from Calatomic (54984 Terminal Annex, Los Angeles, Calif., U.S.A.). This material contained approximately $50 \%$ of its radioactivity as meso- $\mathrm{A}_{2} \mathrm{pm}, 25 \%$ as $\mathrm{LL}-\mathrm{A}_{2} \mathrm{pm}$ and $25 \%$ as DD- $\mathrm{A}_{2} \mathrm{pm}$. Synthetic $\mathrm{A}_{2} \mathrm{pm}$ (unlabelled) was made as described by Saleh \& White (1976).

\section{RESULTS}

\section{The free amino acid pool of B. megaterium 7581}

Exponential phase organisms (grown in medium A2) contained only a few detectable free amino acids in the pool $(\mathrm{mm})$ : glutamate, 140; alanine, 12; glycine, 8 ; serine, 5; lysine, 5 ; ornithine, $4 ; \mathrm{A}_{2} \mathrm{pm}, 4$. The $\mathrm{A}_{2} \mathrm{pm}$ was made up of $84 \%(\mathrm{w} / \mathrm{w})$ meso- and $16 \%$ LLisomers; no DD-isomer was detected by chromatography or colorimetric assay after treatment of the pool $\mathrm{A}_{2} \mathrm{pm}$ with diaminopimelate epimerase and diaminopimelate decarboxylase. The absence of $\mathrm{DD}-\mathrm{A}_{2} \mathrm{pm}$ does not prove that this isomer has no metabolic role; several amino acids that must be important intermediary metabolites (e.g. aromatic amino acids, aspartate, histidine) were also not detected in the amino acid pool of B. megaterium 7581 .

\section{Uptake of isomers of $A_{2}$ pm during growth of $B$. megaterium}

The rate of exponential growth of $B$. megaterium 7581 was unaltered by the presence of $\mathrm{A}_{2} \mathrm{pm}$. The rate of uptake of meso- $\mathrm{A}_{2} \mathrm{pm}$ reached a maximum when $50 \mu \mathrm{g} \mathrm{ml}^{-1}$ was used. About $30 \mu \mathrm{g}$ meso- $\mathrm{A}_{2} \mathrm{pm}$ was taken up during growth of $1 \mathrm{mg}$ dry wt bacteria; this represents about half the total $\mathrm{A}_{2}$ pm needed by the organisms for synthesis of wall and protein. (About $500 \mu \mathrm{g}$ protein, containing, say, $25 \mu \mathrm{g}$ lysine, and about $250 \mu \mathrm{g}$ wall, containing approximately $125 \mu \mathrm{g}$ peptidoglycan, equivalent to $25 \mu \mathrm{g} \mathrm{A}_{2} \mathrm{pm}$, are present per $\mathrm{mg}$ bacteria.) Synthetic $\mathrm{A}_{2} \mathrm{pm}\left(50 \mu \mathrm{g} \mathrm{ml}^{-1}\right)$ was taken up slightly more slowly. It was possible, therefore, that the organisms were not equally permeable to all three isomers of $A_{2} p m$, and 

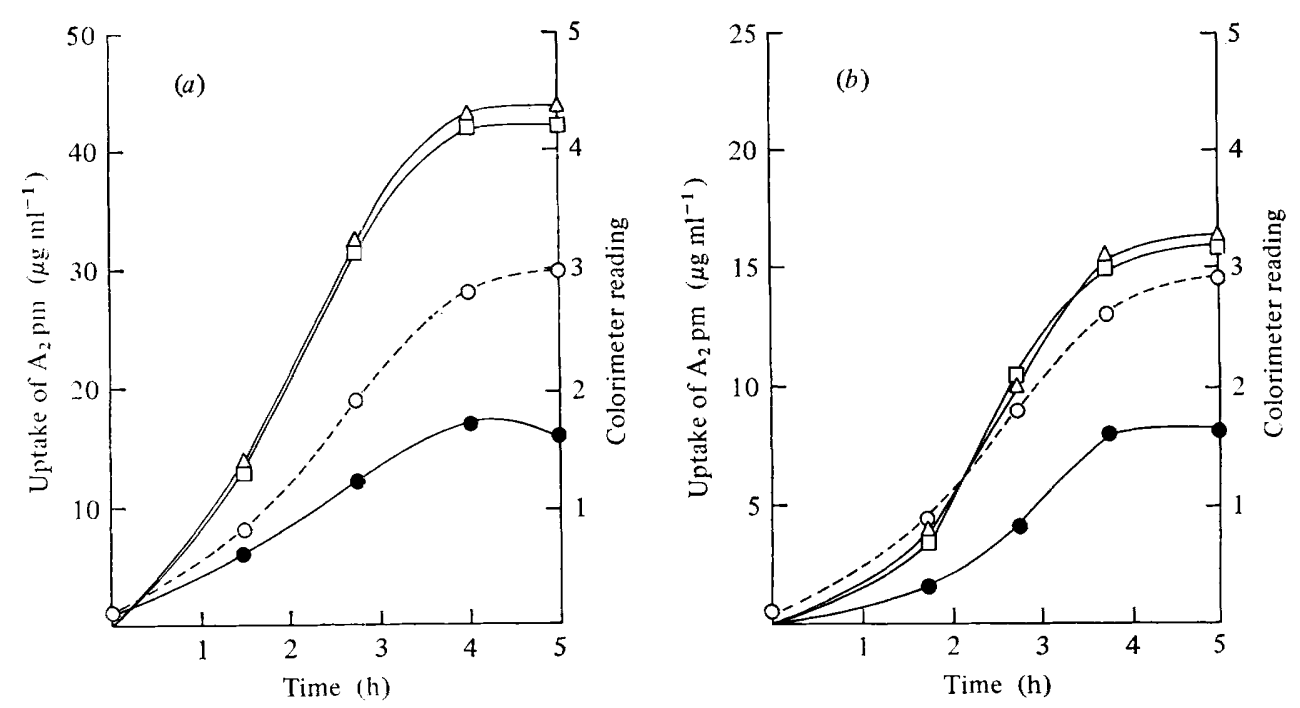

Fig. 1. Comparison of the uptakes of the three isomers of $\mathrm{A}_{2} \mathrm{pm}$ (each initially $50 \mu \mathrm{g} \mathrm{ml}^{-1}$ ) by growing cultures of $B$. megaterium 7581: (a) medium A2 plus $\mathrm{A}_{2} \mathrm{pm} ;(b)$ medium $\mathrm{A} 2$ plus $\mathrm{A}_{2} \mathrm{pm}$ and $\mathrm{L}-$ lysine $\left(50 \mu \mathrm{g} \mathrm{ml}^{-1}\right)$. The $\mathrm{A}_{2} \mathrm{pm}$ that remained in the mediun was measured at intervals and the amount that had disappeared (since zero time) was assumed to represent the uptake of the amino acid: $O$, turbidity of the culture (colorimeter reading); $\triangle$, meso- $\mathrm{A}_{2} \mathrm{pm} ; \square, \mathrm{LL}-\mathrm{A}_{2} \mathrm{pm}$; $\boldsymbol{Q}$, DD$\mathrm{A}_{2} \mathrm{pm}$.

so the uptakes of the isomers were compared (Fig. $1 a$ ). The rates of uptake of meso- and LL-isomers were similar, but DD- $\mathrm{A}_{2} \mathrm{pm}$ was taken up more slowly. When the organisms reached the stationary phase (about $1.5 \mathrm{mg}$ dry wt $\mathrm{ml}^{-1}$ ) $85 \%$ of the meso- or LL- $\mathrm{A}_{2} \mathrm{pm}$ had been taken up, while only $30 \%$ of the $\mathrm{DD}$-isomer had disappeared from the medium. Later experiments (see below) showed that the rate of uptake of radioactivity supplied as $\mathrm{A}_{2} \mathrm{pm}$ in medium containing lysine closely matched the rate of disappearance of $\mathrm{A}_{2} \mathrm{pm}$, and that most of the radioactivity taken up remained in the form of $A_{2} p m$ within the organisms.

\section{Incorporation of $A_{2}$ pm into peptidoglycan}

The $\mathrm{A}_{2} \mathrm{pm}$ that is taken up by growing organisms may enter the free amino acid pool, some may be incorporated into peptidoglycan and some may be decarboxylated to lysine and then incorporated into protein. In experiments with $\left[{ }^{14} \mathrm{C}\right] \mathrm{A}_{2} \mathrm{pm}$, cultures were always grown with lysine added to the medium to repress or inhibit diaminopimelate decarboxylase (White et al., 1964; Rosner, 1975). With $B$. megaterium 7581, the activities of this enzyme (assayed manometrically in the absence of lysine; White, 1971) were [ $\mathrm{nmol} \mathrm{min}{ }^{-1}$ (mg protein) ${ }^{-1}$ ]: 6.3 in organisms from minimal medium A2, and 3.6 in organisms from medium plus lysine and $\mathrm{A}_{2} \mathrm{pm}$ (both $50 \mu \mathrm{g} \mathrm{ml}^{-1}$ ). When lysine was present in the medium, the amount of meso- $\mathrm{A}_{2}$ pm taken up was decreased to less than half (Fig. $1 b$ ), presumably because $A_{2}$ pm was no longer used as a precursor of lysine, though lysine might perhaps also compete with $\mathrm{A}_{2} \mathrm{pm}$ for entry into the bacteria. The uptakes of the LL- and DD-isomers were also decreased in the presence of lysine.

When organisms were grown with synthetic $\left[{ }^{14} \mathrm{C}\right] \mathrm{A}_{2} \mathrm{pm}\left(50 \mu \mathrm{g} \mathrm{ml}^{-1} ; 0.01 \mu \mathrm{Ci} \mathrm{ml}{ }^{-1}\right)$ and L-lysine $\left(50 \mu \mathrm{g} \mathrm{ml}^{-1}\right)$ in $20 \mathrm{ml}$ medium A2, radioautograms (solvent 1) of the hydrolysates of the whole organisms (see Methods) showed some labelling of lysine (14\% of the total radioactivity present, which implies that about $25 \%$ of the $\left[{ }^{14} \mathrm{C}\right] \mathrm{A}_{2} \mathrm{pm}$ taken up was decarboxylated) but most of the radioactivity was present as $\mathrm{A}_{2} \mathrm{pm}$. The hydrolysates of 
Table 1. Proportions of $\left[{ }^{14} \mathrm{C}\right] \mathrm{A}_{2}$ pm isomers in the peptidoglycan of $B$. megaterium 7581 after growth with individual isomers of $\left[{ }^{14} \mathrm{C}\right] \mathrm{A}_{2} \mathrm{pm}$ and unlabelled lysine

Organisms were grown in medium A2 (as described in Methods) with L-lysine (50 $\mu \mathrm{g} \mathrm{ml}^{-1}$ ) and individual isomers (each $50 \mu \mathrm{g} \mathrm{ml}^{-1}$ ) of $\left[{ }^{14} \mathrm{C}\right] \mathrm{A}_{2} \mathrm{pm}$. Peptidoglycan was isolated when growth had reached about $1 \mathrm{mg} \mathrm{ml}^{-1}$ (late-exponential phase); the peptidoglycan was hydrolysed with acid and the proportions of the isomers of $\left[{ }^{14} \mathrm{C}\right] \mathrm{A}_{2} \mathrm{pm}$ were determined in the hydrolysate.

\begin{tabular}{|c|c|}
\hline $\begin{array}{l}\text { Isomers of }\left[{ }^{14} \mathrm{C}\right] \mathrm{A}_{2} \mathrm{pm} \\
\text { supplied in medium } \\
\left(\mu \mathrm{Ci} \mathrm{ml}{ }^{-1}\right)\end{array}$ & $\begin{array}{l}\text { Total uptake } \\
\text { of }\left[{ }^{14} \mathrm{C}\right] \mathrm{A}_{2} \mathrm{pm} \\
\left.(\mathrm{nCi} \mathrm{ml}]^{-1}\right)\end{array}$ \\
\hline meso- $(0.013)$ & 5.9 \\
\hline LL- $\quad(0.011)$ & $4 \cdot 1$ \\
\hline DD- $\quad(0.010)$ & $1 \cdot 6$ \\
\hline Unresolved $(0 \cdot 010)$ & $3 \cdot 5$ \\
\hline
\end{tabular}

Isomers of $\left.{ }^{\left[{ }^{14}\right.} \mathrm{C}\right] \mathrm{A}_{2} \mathrm{pm}$ in peptidoglycan (\% of total $\left[{ }^{14} \mathrm{C}\right] \mathrm{A}_{2} \mathrm{pm}$ present in hydrolysate)

$\begin{array}{crc}\text { meso- } & \text { LL- } & \text { DD- } \\ 89 & 7 & 4 \\ 82 & 18 & \text { Trace } \\ 86 & 0 & 14 \\ 85 & 9 & 6\end{array}$

In every case, at least $70 \%$ of the total $\left[{ }^{14} \mathrm{C}\right] \mathrm{A}_{2} \mathrm{pm}$ taken up was present in the isolated peptidoglycan, as $\left.{ }^{[14} \mathrm{C}\right] \mathrm{A}_{2} \mathrm{pm}$.

peptidoglycan (see Methods) contained at least $95 \%$ of the radioactivity as $\mathrm{A}_{2} \mathrm{pm}$, the remainder being present as lysine, which might indicate some contamination of the peptidoglycan by protein.

When organisms were grown in medium A2 $(20 \mathrm{ml})$ plus L-lysine $\left(50 \mu \mathrm{g} \mathrm{ml}^{-1}\right)$ and individual isomers of $\left[{ }^{14} \mathrm{C}\right] \mathrm{A}_{2} \mathrm{pm}$ (each at $50 \mu \mathrm{g} \mathrm{ml}^{-1} ; 0.01 \mathrm{Ci} \mathrm{ml}^{-1}$ ), the observed uptakes of the $\left[{ }^{14} \mathrm{C}\right] \mathrm{A}_{2} \mathrm{pm}$ isomers, measured by scintillation counting, were similar to those of the unlabelled isomers in the presence of lysine (Fig. $1 b$ ). The peptidoglycan samples were hydrolysed with acid and assayed (see Methods) for the proportions of meso-, LL- and DD$\left[{ }^{14} \mathrm{C}\right] \mathrm{A}_{2} \mathrm{pm}$ that they contained (Table 1 ).

When radioactivity was supplied in the medium as DD- $\mathrm{A}_{2} \mathrm{pm}$, most $(86 \%)$ of the labelling in the isolated peptidoglycan was in the form of meso-[ $\left[{ }^{14} \mathrm{C}\right] \mathrm{A}_{2} \mathrm{pm}$, suggesting that DD- $\mathrm{A}_{2} \mathrm{pm}$

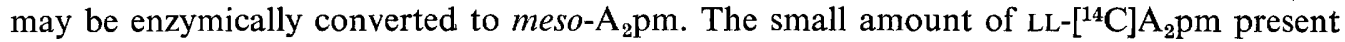
in the $\mathrm{DD}-\left[{ }^{14} \mathrm{C}\right] \mathrm{A}_{2} \mathrm{pm}$ could, of course, also give rise to meso- $\left[{ }^{14} \mathrm{C}\right] \mathrm{A}_{2} \mathrm{pm}$ by the action of diaminopimelate epimerase. However, the amount of radioactivity incorporated into peptidoglycan as meso- $\mathrm{A}_{2} \mathrm{pm}$ after growth with $\mathrm{DD}-\left[{ }^{14} \mathrm{C}\right] \mathrm{A}_{2} \mathrm{pm}$ was twice the total amount of radioactivity present initially in the medium as contaminating LL-isomer, and no labelled LL- $\mathrm{A}_{2} \mathrm{pm}$ was found in the peptidoglycan, suggesting that little ${ }_{\mathrm{LL}}-\left[{ }^{14} \mathrm{C}\right] \mathrm{A}_{2} \mathrm{pm}$ was actually taken up. Supplying DD- $\left[{ }^{14} \mathrm{C}\right] \mathrm{A}_{2} \mathrm{pm}$ in the medium also led to an increased proportion of the radioactivity in the peptidoglycan being in the form of ${ }_{D D}\left[{ }^{14} \mathrm{C}\right] \mathrm{A}_{2} \mathrm{pm}$. This result is consistent only with the $\mathrm{DD}$-isomer being incorporated as such. If the DD- $\mathrm{A}_{2} \mathrm{pm}$ in the hydrolysed peptidoglycan had arisen solely by acid-induced isomerization of meso- or LL- $\mathrm{A}_{2} \mathrm{pm}$ residues, then ${ }_{\mathrm{DD}}-\left[{ }^{14} \mathrm{C}\right] \mathrm{A}_{2} \mathrm{pm}$ would have been found in high proportion when meso$\left[{ }^{14} \mathrm{C}\right] \mathrm{A}_{2} \mathrm{pm}$ or $\mathrm{LL}-\left[{ }^{14} \mathrm{C}\right] \mathrm{A}_{2} \mathrm{pm}$ were supplied in the medium; DD- $\left[{ }^{14} \mathrm{C}\right] \mathrm{A}_{2} \mathrm{pm}$ would have only labelled the peptidoglycan after isomerization to meso- or LL-A $\mathrm{A}_{2} \mathrm{pm}$.

The pattern of labelled isomers in the peptidoglycan after growth with radioactive LLor meso- $\mathrm{A}_{2} \mathrm{pm}$ is consistent with the known interconversion of these two isomers (White et al., 1969). Some DD- $\left[{ }^{14} \mathrm{C}\right] \mathrm{A}_{2} \mathrm{pm}$ was found in the peptidoglycan after growth with meso$\left[{ }^{14} \mathrm{C}\right] \mathrm{A}_{2} \mathrm{pm}$, but the radioactivity in the DD-isomer was only one-third of that added to the medium as DD- $\left[{ }^{14} \mathrm{C}\right] \mathrm{A}_{2} \mathrm{pm}$ present as an impurity in meso- $\left[{ }^{14} \mathrm{C}\right] \mathrm{A}_{2} \mathrm{pm}$. On the other hand, the $\mathrm{LL}_{-}\left[{ }^{14} \mathrm{C}\right] \mathrm{A}_{2} \mathrm{pm}$ contained nearly as much contaminating $\mathrm{DD}-\left[{ }^{14} \mathrm{C}\right] \mathrm{A}_{2} \mathrm{pm}$ but gave very little $\mathrm{DD}-\left[{ }^{14} \mathrm{C}\right] \mathrm{A}_{2} \mathrm{pm}$ in the peptidoglycan.

\section{Entry of $A_{2}$ pm into the free amino pool acid}

The rate of uptake of DD- $\mathrm{A}_{2} \mathrm{pm}$ by growing cultures was less than the rates of uptakes of the meso- or LL-isomers (see above), and this difference could have been due to a lower 
rate of entry of the DD-isomer or to a lower rate of its incorporation, or to both. The uptakes of DD- and LL-A $\mathrm{A}_{2} \mathrm{pm}$ into pool and into covalently bound material were compared during exponential growth in medium A2 containing lysine (see Methods). With each isomer, less than $10 \%$ of the $\mathrm{A}_{2} \mathrm{pm}$ taken up by the organisms was extractable by trichloroacetic acid at any time.

\section{DISCUSSION}

Separation of LL- and $\mathrm{DD}-\left[{ }^{14} \mathrm{C}\right] \mathrm{A}_{2} \mathrm{pm}$ with relatively high specific activity and free of meso-isomer is fairly easy. It is more difficult to obtain pure meso- $\left[{ }^{14} \mathrm{C}\right] \mathrm{A}_{2} \mathrm{pm}$ of high specific activity and purity; the method described in this paper is not very satisfactory.

Unlike E. coli (Leive \& Davis, 1965), B. megaterium can readily take up meso- or LL$\mathrm{A}_{2} \mathrm{pm}$ during growth (cf. Pitel \& Gilvarg, 1970; Saleh \& White, 1976). There is stereochemical specificity of uptake, the DD-isomer being taken up at less than half the rate of the LL-isomer. Little $\left[{ }^{14} \mathrm{C}\right] \mathrm{A}_{2} \mathrm{pm}$ is accumulated in a free amino pool, which could mean that the speed of entry rather than of utilization limits the rate of uptake.

The proportions of the different radioactive isomers found in the peptidoglycan in these experiments do not necessarily reflect closely the proportions of total $\mathrm{A}_{2} \mathrm{pm}\left({ }^{14} \mathrm{C}\right.$ - and $\left.{ }^{12} \mathrm{C}-\right)$ actually present in the wall, because the extents to which synthesis of the different isomers of $\mathrm{A}_{2} \mathrm{pm}$ from glucose and their incorporation continue, even when $\mathrm{A}_{2} \mathrm{pm}$ and lysine are supplied to the medium, are not known. However, with this reservation, the results suggest that meso- and $\mathrm{DD}-\mathrm{A}_{2} \mathrm{pm}$ may be directly interconvertible, while LL- and DD- $\mathrm{A}_{2} \mathrm{pm}$ may not be, thus: Glucose $-\rightarrow$ LL-A $\mathrm{A}_{2} \mathrm{pm} \rightleftharpoons$ meso- $\mathrm{A}_{2} \mathrm{pm} \rightleftharpoons \mathrm{DD}-\mathrm{A}_{2} \mathrm{pm}$.

Metabolism of DD- $\mathrm{A}_{2} \mathrm{pm}$ by growing organisms has not previously been reported. Mutants of $E$. coli that required $\mathrm{A}_{2} \mathrm{pm}$ (plus lysine) for growth (Meadow et al., 1957) did not respond to the DD-isomer, nor did a diaminopimelate-requiring mutant of $B$. megaterium (Pitel \& Gilvarg, 1970). Saleh \& White (1976) used the inability of a diaminopimelate-

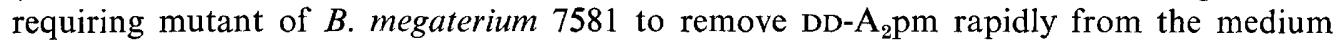
during its growth as a means of resolving $\mathrm{DD}-\mathrm{A}_{2} \mathrm{pm}$ from a racemic mixture with the LLisomer. The present study shows that DD- $\mathrm{A}_{2} \mathrm{pm}$ can be taken up by $B$. megaterium 7581 and incorporated as such into peptidoglycan. More interestingly, the DD- $\mathrm{A}_{2} \mathrm{pm}$ was partly converted to meso- $\mathrm{A}_{2} \mathrm{pm}$, presumably by epimerization at $\mathrm{C}-2$ of the DD-isomer. If, like LL-diaminopimelate 2-epimerase, this suggested enzyme-catalysed reaction were reversible, then it would provide a route for synthesis of the DD-A $\mathrm{A}_{2} \mathrm{pm}$ found in the walls of $B$. megaterium. Preliminary attempts (unpublished) to recognize such an enzyme in extracts of $B$. megaterium have been unsuccessful. Other enzymes that can use DD- $\mathrm{A}_{2} \mathrm{pm}$ as a substrate have been described: Meadow \& Work (1958) found that transamination between DD$\mathrm{A}_{2} \mathrm{pm}$ and 2-keto acids was catalysed by extracts of several bacteria; and Wickus \& Strominger (1972) showed that an enzyme system from B. megaterium QMB1551 could add DD- $\mathrm{A}_{2} \mathrm{pm}$ to a peptidoglycan precursor.

A.D. was supported by a postgraduate studentship from the Science Research Council. We thank Dr W. Ferdinand (Department of Biochemistry, University of Sheffield) for amino acid analysis, and Chas. Pfizer and Co., Groton, Conn., U.S.A. for a gift of diaminopimelic acid.

\section{REFERENCES}

DAY, A. \& WHITE, P. J. (1977). Enzymic assays for isomers of 2,6-diaminopimelic acid in walls of Bacillus cereus and Bacillus megaterium. Biochemical Journal 161, 677-685.

Leive, L. \& Davis, B. D. (1965). The transport of diaminopimelate and cystine in Escherichia coli. Journal of Biological Chemistry 240, 4362-4369.

MEAdow, P. M. \& Work, E. (1958). Bacterial transamination of the stereoisomers of diaminopimelic acid and lysine. Biochimica et biophysica acta 28, 596-599.

Meadow, P. M., Hoare, D. S. \& Work, E. (1957). Interrelationships between lysine and $\alpha \epsilon$-diaminopimelic acid and their derivatives and analogues in mutants of Escherichia coli. Biochemical Journal 66, 270-282. 
PARK, J. T. \& HANCOCK, R. (1960). A fractionation procedure for studies of the synthesis of cell-wall mucopeptide and of other polymers in cells of Staphylococcus aureus. Journal of General Microbiology 22, 249-258.

Perkins, H. R. (1965). 2,6-Diamino-3-hydroxypimelic acid in microbial cell wall mucopeptide. Nature, London 208, 872-873.

Pitel, D. W. \& Gilvarg, C. (1970). Mucopeptide metabolism during growth and sporulation in Bacillus megaterium. Journal of Biological Chemistry 245, 6711-6717.

Rhuland, L. E., Work, E., Denman, R. F. \& HoARe, D. S. (1955). The behaviour of isomers of $\alpha, \epsilon$-diaminopimelic acid on paper chromatograms. Journal of the American Chemical Society 77, 4844-4846.

Rosner, A. (1975). Control of lysine biosynthesis in Bacillus subtilis: inhibition of diaminopimelate decarboxylase by lysine. Journal of Bacteriology 121, 20-28.

SAleh, F. \& White, P. J. (1976). Use of auxotrophic mutants to isolate $\mathrm{LL}$ - or DD-isomers of 2,6 diaminopimelic acid. Journal of General Microbiology 96, 253-261.
Tempest, D. W., Meers, J. L. \& Brown, C. M. (1970). Influence of environment on the content and composition of microbial free amino acid pools. Journal of General Microbiology 64, 171185.

White, P. J. (1971). Diaminopimelate decarboxylase (Escherichia coli). Methods in Enzymology 17B, 140-145.

White, P. J. (1972). The nutrition of Bacillus megaterium and Bacillus cereus. Journal of General Microbiology 71, 505-514.

White, P. J., Kelly, B., Suffling, A. \& Work, E. (1964). Variation of activity of bacterial diaminopimelate decarboxylase under different conditions of growth. Biochemical Journal 91, 600-610.

White, P. J., Lejeune, B. \& Work, E. (1969). Assay and properties of diaminopimelate epimerase from Bacillus megaterium. Biochemical Journal 113, 589-601.

Wickus, G. G. \& Strominger, J. L. (1972). Penicillin-sensitive transpeptidation during peptidoglycan biosyrithesis in cell-free preparations from Bacillus megaterium. 1. Incorporation of free diaminopimelic acid into peptidoglycan. Journal of Biological Chemistry 247, 5297-5306. 